\title{
ШЕЛКОВЫЙ ПУТЬ И СТРАНЫ ЦЕНТРАЛЬНОЙ АЗИИ
}

\author{
(c) 2020 Юй Ян
}

аспирант, кафедра «Мировой экономики и международных экономических отношений» Санкт-Петербургский государственный экономический университет, Россия, Санкт-Петербург

E-mail: dameiels123@gmail.com

\section{(c) 2020 Панин Вадим Викторович}

кандидат экономических наук, доцент

Санкт-Петербургский государственный экономический университет, Россия, Санкт-Петербург

В статье представлен анализ взаимодействия Китая и стран Центральной Азии, проанализированы ключевые аспекты сотрудничества и его динамку в экономической и инвестиционной сферах, а также в области культуры.

Ключевые слова: шелковый путь, страны Центральной Азии, КНР, Пояс и путь.

Несмотря на то, что Центральная Азия стратегически расположена на стыке Европы и Азии, она долгое время была слабо связана: удаленная, не имеющая выхода к морю, отрезанная от основных населенных центров Европы и Азии пустынными степями и скалистыми горами. Помимо физических барьеров, регулятивные препятствия и политические репрессии часто препятствуют свободному потоку людей, товаров, услуг и идей. Однако в 2013 году Китай объявил о своей инициативе «Пояс и путь» (BRI), одной из целей которой является возрождение исторического торгового пути Шелкового пути, соединяющего Европу с Дальним Востоком через Центральную Азию [2].

Де-факто роль Китая как главного игрока в экономике и развитии Центральной Азии остается непризнанной в официальных и общественных дискурсах из-за преобладания в регионе политики, основанной на мнениях. Несмотря на то, что в развитых странах выработка политики на основе фактических данных хорошо зарекомендовала себя, центральноазиатские государства еще не в полной мере испытали преимущества осознанного принятия решений. Центральноазиатские лидеры должны пересмотреть свой подход к Китаю и использовать возможности такого соседства более прагматично и взаимовыгодно. В этой связи возглавляемая Пекином инициатива «Один пояс, один путь» предоставляет прекрасную возможность центральноазиатскому руководству практиковать принятие решений на основе фактических данных и извлекать выгоду из готовности Китая продвигать региональную интеграцию на благо более широкого населения [4].

Центральноазиатский регион является «центральным» для евразийских амбиций Пекина связать запад Китая с Южной Азией, Ближним Востоком и Европой, тем самым уменьшая зависимость страны от морских путей, которые уязвимы для американского морского превосходства. Например, строится экономический коридор Китай-Центральная Азия-Западная Азия, который свяжет Китай с Персидским заливом через Иран и порт Эгейское море / Пирей через Турцию. Кроме того, железнодорожные маршруты ЮРСО в Средний коридор Турции через Казахстан и Каспийское море значительно сокращают время в пути на рынки Ближнего Востока и Европы.

Центральная Азия также ценна сама по себе из-за наличия в регионе углеводородных и минеральных ресурсов, которые Пекин считает неотъемлемой частью поддержания своего экономического роста. Поскольку более половины своей нефти поступает с Ближнего Востока, а более 80 процентов импорта поступает по морю, Китай ищет поставщиков нефти на суше, чтобы диверсифицировать и повысить свою энергетическую безопасность. В настоящее время китайские компании контролируют более четверти добычи нефти в Казахстане. Почти весь экспорт природного газа из региона идет в Китай по газопроводу Центральная Азия-Китай, который был построен на китайские кредиты. Этот регион также является важным поставщиком редкоземельных и других металлов, используемых в Китае для производства высокотехнологичных изделий, таких как солнечные панели и аккуму- 
ляторные батареи.

Кроме того, географическая и культурная близость Центральной Азии к беспокойному Синьцзянскому региону Китая информирует Пекин о сосредоточении внимания на этих государствах. Поскольку три из шести коридоров Бри проходят через Синьцзян, Пекин надеется, что экономическое развитие принесет социальный мир и политическую стабильность Синьцзяну, а также его ближайшим западным соседям.

Что касается Центральной Азии, то ее правительства полагаются на китайские займы как на экономический инструмент стимулирования местного развития. Региональная инфраструктура является неадекватной и устаревшей, а местные фонды-дефицитными. Ожидается, что крупные и мелкие проекты в рамках Southern Regional Education Board (Южный Региональный Совет по Образованию, далее - ЮРСО) - автомобильные и железные дороги, трубопроводы, индустриальные парки и особые экономические зоны-будут способствовать расширению связей и расширению торговли внутри региона и с более широким евразийским континентом. Следовательно, легитимность авторитарных режимов в регионе будет укрепляться.

Кроме того, займы, связанные с ЮРСО, не обусловлены политическими, экономическими или правозащитными реформами, в отличие от займов и прямых грантов, предоставляемых EC, Японией или многосторонними кредитными агентствами. Поэтому они более привлекательны для авторитарных вотчинных режимов Центральной Азии. Некоторые из этих средств затем направляются сторонникам режима, чьи компании прямо или косвенно участвуют в проектах ЮРСО.

Товарооборот между Китаем и Центральной Азией удвоился почти до 40 миллиардов долларов в период с 2007 по 2018 год (рисунок 1), и Китай также является ведущим иностранным инвестором в таких важных секторах, как энергетика, промышленность и инфраструктура. Эта беспрецедентная зависимость от китайской торговли, инвестиций и взаимосвязанности инфраструктуры маскирует ряд рисков для Китая и, как следствие, для центральноазиатских режимов.

Некоторые китайские инвестиционные проекты, как представляется, имеют ограниченные выгоды для широких слоев населения. Они сопровождаются обвинениями в слабом регулировании и, по-видимому, являются средствами, которые позволяют местным элитам захватывать ренты, связанные с Сребреницей. По словам Оливера Стюэнкеля, китайские чиновники в частном порядке признали, что до 30 процентов их инвестиций в ЮРСО в Центральной Азии теряются из-за коррупции. Китай также поощряет неконкурентные закупки, такие как предоставление китайской компании ТВЕА исключительных прав на реконструкцию Бишкекской электростанции за \$ 385 млн. или реконструкцию китайскими подрядчиками автодороги Душанбе-Чанак с привлечением кредита в размере \$ 300 млн. Коррупционные скандалы не давали покоя этим проектам.

Китай является единственным крупнейшим кредитором в некоторых центральноазиатских государствах. В докладе Центра глобального

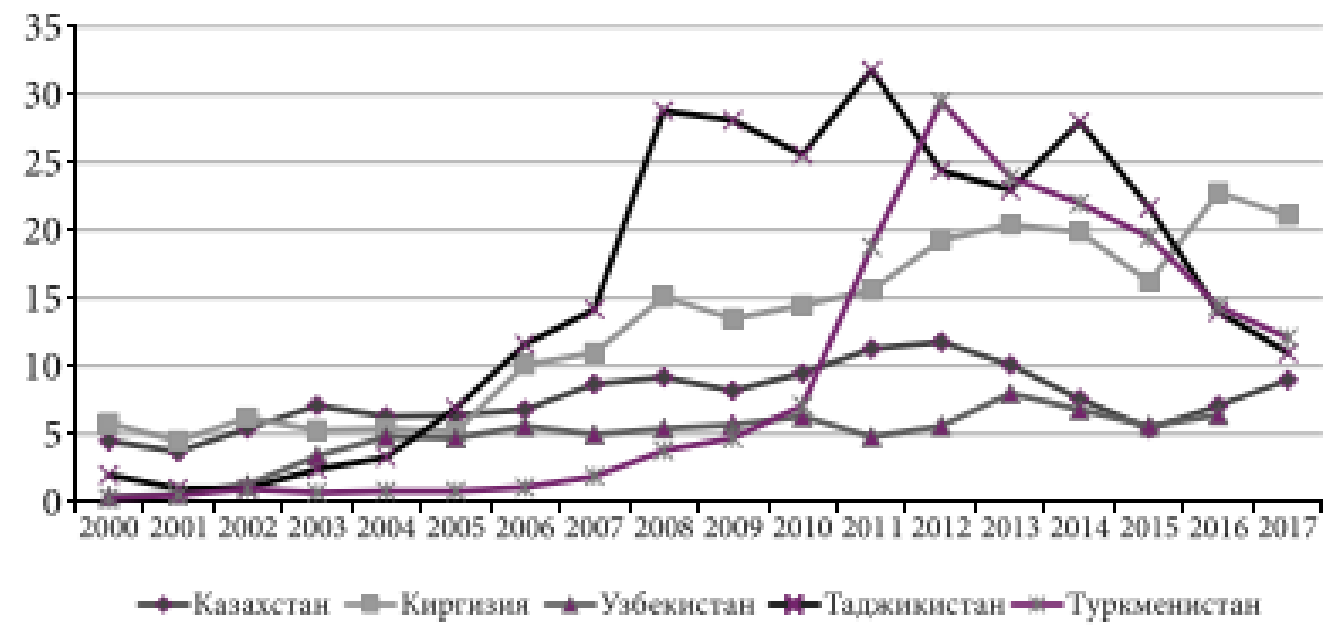

Рис. 1. Динамика товарооборота КНР с государствами ЦА в 2000-2017 гг.,\% к ВВП [1] 
развития, в котором рассматривались долговые последствия 67 стран с проектами, связанными с БРИК, указывается, что две центральноазиатские страны - Кыргызстан и Таджикистан находятся в самой высокой категории риска. В то время как привлечение долга для финансирования инфраструктурных проектов может стимулировать местную экономику, слишком большой долг опасен, если он не может стимулировать местную экономику и генерировать крупномасштабные доходы и отдачу в местные бюджеты. Пекин уже обвиняют в сговоре с авторитарными режимами с целью хищения ресурсов с ограниченным вкладом в развитие страны.

В докладе, сравнивающем проекты, финансируемые Китаем и многосторонними партнерами, было установлено, что 89 процентов подрядчиков были китайцами и 7,6 процентаместными жителями в проектах, финансируемых Китаем, в то время как 29 процентов были китайцами и 41 процент - местными жителями в проектах, финансируемых многосторонними партнерами. Из-за отсутствия сильных требований к местному содержанию местные фирмы часто получают короткие сроки, и проекты переходят к китайским подрядчикам и рабочим. Например, дороги Ош-Сарыташ-Иркештам и Бишкек-Нарын-Торугат в Кыргызстане, частично финансируемые Китаем, были построены за счет рабочей силы, состоящей на 30\% из местных жителей и на 70\% из китайских рабочих, а 60\% - из импортного сырья. Следовательно, выгоды для местной экономики умеряются.

Гнев по поводу коррупции в элитах и озабоченность экологическими последствиями финансируемых Китаем проектов подпитывают антикитайские и, как следствие, антирежимные - настроения среди населения региона. В начале 2016 года в крупных казахстанских городах вспыхнули протесты против попыток выделения сельскохозяйственных земель в долгосрочную аренду, поскольку основным бенефициаром считался Китай. Совсем недавно, в январе 2019 года, в Бишкеке состоялся антикитайский митинг, названный «самым большим общественным протестом на сегодняшний день в Центральной Азии против растущего влияния Пекина»; протестующие призывали к контролю за выдачей разрешений на работу китайским гражданам и китайско-киргизским бракам, а также к сокращению задолженности Кыргызстана перед Китаем.

Участвуя в ЮРСО, центральноазиатские государства надеются уравновесить требования традиционного культурного гегемона региона России с требованиями его экономического гегемона - Китая. Поскольку и Москва, и Пекин активизировали реализацию региональных интеграционных инициатив, это открыло возможности для коварных центральноазиатских лидеров получить некоторую автономию. Например, вместо того чтобы пассивно принимать финансирование ЮРСО со стороны Китая, лидеры Казахстана и Кыргызстана ведут переговоры с Китаем о увязке местных концепций экономического развития («Нұрлы жол» в Казахстане или «таза Кум» в Кыргызстане) с ЮРСО. Что касается Узбекистана, то он уравновесил финансируемый ЮРСО Камчикский железнодорожный тоннель льготными кредитами от России для своей первой в истории атомной электростанции [3].

Углубление финансово-инвестиционного сотрудничества с Китаем не несет угроз национальным интересам других стран и может рассматриваться как механизм решения многих проблем развития.

\section{Библиографический список}

1. Тураева М.О., Глинкина С. П., Яковлев А.А. Каналы проникновения китайского капитала в республики Центральной Азии в рамках инициативы «один пояс - один путь» // Journal of new economy. 2018. № 4. URL: https://cyberleninka.ru/article/n/kanaly-proniknoveniya-kitayskogo-kapitala-v-respubliki-tsentralnoy-azii-vramkah-initsiativy-odin-poyas-odin-put (дата обращения: 14.03.2020).

2. Russell M. Connectivity in Central Asia: Reconnecting the Silk Road. URL: https://www.europarl.europa.eu/ thinktank/en/document.html?reference=EPRS_BRI(2019)637891 (дата обращения: 11.03.2020г.).

3. S. Li-Chen, Aminjonov F, Potholes and Bumps Along the Silk Road Economic Belt in Central Asia. February 01, 2020. URL: $\quad$ https://thediplomat.com/2020/02/potholes-and-bumps-along-the-silk-road-economic-belt-in-centralasia/ (дата обращения: 11.03.2020 г.).

4. Toktomushev K. Central Asia and the Silk Road Economic Belt. Policy brief 2016-1. Graduate school of development. Institute of Public Policy and Administration. URL: https:/ucentralasia.org/Content/downloads/Central\%20 Asia\%20and\%20the\%20Silk\%20Road\%20Economic\%20Belt.pdf (дата обращения: 11.03.2020 г.). 